\title{
KNOWLEDGE TRANSMISSION OF PALEMBANG ISLAMIC ULAMA DURING PALEMBANG SOULTANATE TO COLONIAL ERA
}

\author{
Herlina \\ Universitas Islam Negeri Raden Fatah Palembang \\ Email: herlina_uin@radenfatah.ac.id
}

\begin{abstract}
This historiography reveals the transmission of Islamic knowledge historically carried out by Palembang intellectuals, who lived during the Palembang sultanate and still prevailed until the Colonial era, after the Palembang sultanate had fallen and changed to the Palembang residency. This recording history uses historical methods, e.i. heuristics, source criticism, auffassung, and derstallung, while in data analysis it was used social hermeneutics and philological research stages. The results of historical sources, both texts and references which related to the problem of knowledge transmission of Palembang Islamic cleric, identified some Palembang Ulama in this period in transmitting knowledge. They were Shaykh Syihabuddin al-Jawi al-Palembani, Kemas Fakhruddin, Shaykh Sharia Abdus-Samad al-Palimbani, Shaykh Azhary Abdullah, Shaykh Kemas Azhary, and Azhary Imam. Knowledge Transmission of Palembang Ulama consists of two ways; Da'wah Bi Lisan and Da'wah Bi Qalam with scientific fields that include Fikih Akhlak, Tasawuf and Falak, Qur'an and Hadith, Islamic social and culture, Islamic history and Islamic biographies, prayer and remembrance, as well as jihad.
\end{abstract}

Keywords: Palembang Islamic Ulama, Intellectual Traditions Knowledge Transmission

\section{Introduction}

In the Islamic intellectual tradition, there were many activities occurred. One of them wandering to study or rihlah to various teachers or scholars to study the books of famous scholars, and transmit knowledge through the activity of writing intellectual works in the field of religion and translation. Muslim intellectuals who gained knowledge from the process of seeking knowledge are called transmitter. They transmit knowledge to the society where they take part and also to other learners in some places. 
Intellectual tradition, which is carried out by knowledge seekers, is not only aimed at enriching their scientific insights but also enriching their life experiences, because in the process of scientific transmission there is an exchange of knowledge and information from each figure (Azra 2013), and this is also possible because the longer and further of process, the broader one's knowledge (Asrohah 1999). The learners who already had and mastered Islamic knowledge act as transmitters to transmit knowledge that had been obtained from the process of seeking knowledge to the communities in which they take part and also to other claimants of knowledge in various places. According to Munip (Munip 2010) The word Transmitter can be interpreted as something that plays a role in the transmission process. Transmission of intercultural knowledge can be interpreted as knowledge from one particular sociocultural group to another socio-cultural group, such as the transmission of knowledge from Greek culture to Arabic culture, from Arab culture to Europe, from Arabia to Indonesia and others.

Transmission of knowledge carried out both by way of halaqah, and carried out in various places, such as mosques, maktabah, kuttab, majlis, khan, ribath, Manazil alUlama, al-Hawanit al-Warraqien, Al-Badiyah, Khawaniq, libraries, observatories and Madrasah (Asrohah 1999) (Nata 2014). Intellectuals transmitted their knowledge to other learners and also to the people in their surroundings. The transmission of knowledge was carried out by giving $d a^{\prime}$ wah by teaching the knowledge of Islam through halaqah, Majlis, Mosque or at Ulema's house and transmission by indirect means such as through writing ( $\left(a^{\prime}\right.$ wah bil qalam) (Asrohah 1999) (Nata 2014) (Junaedi 2015). Da'wah according to Shaykh Ali Mahfudz, in his book entitled Hidayatul alMursyidin, is "Calling people to virtue and guidance and directing to virtue and forbidding evil in order to obtain world and hereafter happiness" (Alimul H 2009). Therefore, the intellectuals who carried out scientific transmission through writing (da'wah bil qalam), wrote their thoughts in the form of scientific works as well as literary works, and other forms of written works, namely translating the books of Islamic cleris into Malay. 


\section{Research Methods}

This research is a historiography of Islamic Intellectuals which aims to reveal the transmission of Islamic knowledge carried out by Palembang Muslim intellectuals. The research method used in this study was the library literature. The object of the research was the collection of works of Palembang scholars of the $18^{\text {th }}$ century until the beginning of the $20^{\text {th }}$ century. The scholars in this paper were identified as knowledge transmitter during Palembang Sultanate to the colonial period. The subjects of the research were manuscripts by Shaykh Syihabuddin al-Jawi al-Palembani, Fakhruddin's Boarding School, Shaykh Abdus-Samad al-Palimbani, Shaykh Azhary Abdullah, Shaykh Kemas Azhary, and Azhary Imam. Analytical framework of this study used the intellectual history of Crane Brinton. Crane Brinton said that intellectual history is a study that seeks and re-understands the spread of the works of someone who worked in a particular society. Crane also stated that intellectual history was seen from the point of view of narrow thinking, trying to tell the initial producers and how intellectual results. In addition, the intellectual history paradigm also understands non-intellectual factors in general, in the sociology of individuals and society (Abdullah 1996). This writing used the historical method with four historical steps, i.e., Heuristics; at this stage there is some search or discovery of historical sources, especially to the sources of manuscripts related to the evidence of $d a^{\prime}$ wah bil qalam. Source criticism; it critically analyzed historical sources, assessing whether or not there were authentic sources. Auffassung; this steps shows the response to historical facts, taken from historical sources. Synthesis of facts obtained through source criticism or also called source analysis; Derstallung, the presentation of the data in written form. The writing revealed events objectively and realistically (Garraghan 1957), with data analysis doing hermeneutic interpretation to understand the text and context (Littlejohn 1989), and the Philology approach is used to help analyze the texts of Palembang sholars' works (Fathurahman 2015). 


\section{The Condition of Palembang Islamic Knowledge}

The process of Islamization in several regions of the archipelago had occured along with the formation of Islamic scientific traditions, from rihlah in seeking knowledge to the transmission of Islamic knowledge (knowledge transferring) either directly or through writing - intellectual works, into books and translating existing books. All conditions in these various traditions also drew the science and education in Palembang, especially by Palembang Muslim intellectuals (Herlina, 2018):. The development of Islam in Palembang occurred when Palembang had turned into an Islamic kingdom or sultanate, especially when the Palembang sultanate established Islam as the official religion of the kingdom during the reign of Sultan Abdurrahman Kholifatul Mukminin Sayyidul Imam or Sunan Cindeh Walang (1659-1706 AD) (Safwan $2004,32)$

The development of the Islamic religion in the sultanate of Palembang experienced rapid progress and even Palembang became the center for the study of the largest Malay-language Islamic knowledge in the archipelago in the $18^{\text {th }}$ century or around 1750-1820 AD (Steenbrink 1984) and Palembang became a home to a number of prominent Muslim scholars and Malay writers (Drewes 1977). The emergence of Palembang as a center for the study of Islamic science happened when Aceh suffered a setback that occurred at the end of the $17^{\text {th }}$ century. This is likely to occur because at that time there were number of Palembang scholars in developing Islamic knowledge. The development of Islamic knowledge from these Islamic Ulama received full support from the Sultan of Palembang Darussalam. This took place from the $18^{\text {th }}$ century to the beginning of the $19^{\text {th }}$ century by making the Palembang Darussalam or a center for Islamic studies and literature (Rahim 1998). In his study, (Sukardi 2014) stated that the scientific tradition in Palembang started from the Palace or Sultanate palace of Palembang Darussalam. The role and attention of the Palembang sultanate turned the science of religion and Malay literature in Palembang quite developed. The role and attention, among others, is to provide worship facilities such as establishing mosques as centers of religious activity and Palembang sultans themselves as religious people who set an example to their community by becoming prayer leaders at Masjid Agung 
Palembang and inviting scholars to discuss various issues both religious issues and state conditions.

The development of Islam in Palembang and its fame as a center of Malay literature were inseparable from the role of Palembang scholars such as Sheikh Abdus Samad al-Palimbani, Shihabuddin Shihabuddin al-Jawi al-Palimbani, Kemas Fakhruddin Board, Muhammad Muhyidin Bin Shaykh Syihabuddin (Azra 2013). The scholars did transmit Islamic knowledge to the people of Palembang and its surroundings, and there were also those who did it in the palace, and some of them even were appointed as advisors to the empire and translators and copyists of books for the kingdom (Sukardi 2014).

Those writers had existed since the time of Sultan Mahmud Baraduddin I, they are known by the term "Ulama Keraton"(Rahim 1998). The development of Malay religious knowledge and literature in Palembang made the scholars more productive in writing, and carried out traditions and scientific transmissions, both translating religious books or writing literary works and pouring out their thought. From their writings produced intellectual works in various fields both in Islamic sciences such as Sufism, Tauhid, figh, and Malay literature.

Meanwhile, the presence of the Dutch colonial in Palembang and after the transfer of power into Dutch hands in 1823 (Wargadalem 2017). not only had it undermined the political power of Islam in the sultanate of Palembang, the loss of the palace as an institution that sheltered scholars and a place for the development of Islamic sciences, the Islamic scientific tradition and the development of Islamic knowledge and development Islamic science was slowly being transferred to traditional Islamic educational institutions led by independent scholars.

However, the collapse of the Palembang sultanate and its conversion to the Palembang residency did not undermine the spirit of intellectuals of Palembang Muslims and Islamic Ulama to carry out intellectual activities such as Malay Muslim community groups which wandered knowledge in Mecca and Medina, in addition to performing the pilgrimage (Bruinessen 1990, 42-49). Palembang scholars and intellectuals developed their own scientific transmission so that Islamic knowledge 
could still be conveyed and absorbed by the people at that time through various methods and other approaches to worship, such as preaching, studying the book at the mosque, teaching tarekat during halaqah and assemblies, or at the houses of the scholars, as well as the transmission of knowledge by writing the work of his thoughts and translating religious books. This happened because it followed the tradition of the Palembang scholars before in the mid $17^{\text {th }}$ and $18^{\text {th }}$ centuries, which had established a good relationship between the Islamic Ulama of the Archipelago in the MalayIndonesian region and the Haramyn in the Middle East.

\section{Knowledge Transmisson of Palembang Islamic Intellectuals}

Muslim intellectuals who have gained knowledge from the process of seeking knowledge, then they did the transmission of knowledge to the community in which they took part and also to other claimants of knowledge. The transmission of this knowledge can be done in various ways and places such as maktab or kuttab, halaqah, majlis, mosques, khan, ribath, ulemas' houses, bookstores, libraries and observatories (Asrohah 1999). In the transmission of knowledge carried out by Palembang intellectuals, it was done both directly ( $d a^{\prime}$ wah bil lisan) with $d a^{\prime}$ wah and teaching, or indirectly through writing (da'wah bil qalam) (Herlina 2018).

The following findings were related to knowledge transmission made by Palembang scholars from the results of tracing historically the scientific transmission made by Palembang scholars in the process of knowledge transmission carried out during the Palembang Sultanate and Palembang residency (Herlina 2018):

1. Knowledge transmission from Shaykh Syihabuddin al-Jawi al-Palimbani, (1724-1775 AD), there were two modes of transmission carried out by Shaykh Syihabuddin alJawi al Palimbani. First, oral proselytizing, namely transmitting knowledge in Palembang by practicing tarekat such as the Syathariyah, Naqshbandiyah, Qadiriyah and Rifa'iyah tarekat, and even as a propagator of neo-Sufi teachings (Drewes, 1977). Thus, based on this data both as a practitioner and disseminator of the tarekat, it was certain that Shaykh Syihabuddin al Jawi al-Palimbani had quite a number of students both from outside Palembang and from within Palembang 
himself. Second, da'wah bil qalam, Shaykh Syihabuddin al-Jawi al-Palimbani, from the manuscripts of his work can be ascertained the existence of scientific transmission in written form. Shaykh Syihabuddin al-Jawi al-Palimbani has poured the results of his thoughts into writing and also translating Islamic sciences from Arabic scholars into Malay / Jawi (Old Javanese). Works that can be identified as a form of scientific transmission include Jawharat al-Tawhīd (1163 H / 1750 AD), Syarah'Aqāid al-Imān (1162 H / 1748), and the Book of Risālah (1198H / 1783M) (Drewes 1977) (Abdullah 1996)(Herlina 2018).

2. Kemas Fakhruddin's knowledge transmission, the type of scientific transmission found in Fakhruddin's based on manuscript searching was the transmission of knowledge through writing ( $d a^{\prime} w a h$ bi al-qalam), namely translating Arabic books into Malay, so that he was well-known as a translator. Other data related to the scientific activities of Fakhruddin was a developer of Sufism teachings ((Drewes, 1977; and Huda, 2013), so it can be assumed that Fakhruddin also has the possibility of having students from various places. Unfortunately, further information about the students of Fakhruddin had not been traced successfully. As for his works that show the existence of intellectual activity, namely: Tuhfar azzamān fì zarfahl al-yamān (1175 H / 1761 AD), Khawas al-Quran al-'Azìm (1183 H / 1769 AD), As-Sayr wa as-Suluk ila Malik al-Muluk, the Book of Mukhtașar (1238H / 1822 AD), and Jauhar al-ulum (Drewes 1977).

3. Knowledge transmission from Shaykh Abdus-Samad al-Palimbani, (1737-1789 AD). There were several scientific transmission activities carried out by Shaykh Abdus-Samad al-Palimbani, and those transmission activities, namely; da'wah bil lisan and da'wah bil qalam. Oral preaching done by Shaykh Abdus-Samad alPalimbani, such as preaching while traveling and traveling to various regions of the Middle East such as Makkah, Medina, Aden, Zabid, Ruayah (Yemen), Egypt, as well as Malay regions such as Kedah / Patani, and Palembang. He also taught various Islamic knowledges to his students and teaching the practices of the Sammaniyah wirid tarekat such as talqin and bai'at, genealogy, wirid after prayers, musaba'atul 'Asyarah, Samman ratib, hawib Nawawi, hizib Bahr, wirid sahur, and so on. 
The intellectual activity of Shaykh Abdus-Samad al-Palimbani in terms of his scientific transmission were gained by his students, then his knowledge and thought spread. (Syarifuddin 2013).

While, da'wah bil qalam conducted by Shaykh Abdus-Samad al-Palimbani, namely by pouring the results of his thoughts and knowledge into a manuscript. The transmission of knowledge through this writing made Shaykh Abdus-Samad al-Palimbani as one of the Indonesian Ulama who had high intelligence and competence in the field of Islamic knowledge. From this work, it became a source of inspiration for both Nusantara Muslims and foreign Muslims in their time to the present. There are 22 (twenty two) intellectual works from Shaykh Abdus-Samad al-Palimbani, including Zuhrat al-Murìd fì Bayān Kalimat al-Tawhīd (1178 H/1764 M), Risālah fì Bayān Asbāb Muharramā li al-Nikāh (1179 H/1765M), Nashīhat alMuslimīn wa Tadzkirat al-Mu'minìn fì Fadhāil al-Jihād fì Sabīl Allāh (1186 H / 1772 M), Zād al-Muttaqīn fì Tawhīe Rabb al-'Alamīn, Tuhfah Ar-Rāgibīn (1188 H / 1774 M), Al'Urwat al-Wutsqā (1205 H), Al-Risālat fì Kayfiyat al-Ratīb Laylat al-Jumu'ah, Risālah fì al-Awrād wa al-Adzkār, Hidāyat al-Sālikìn fì Suluk Maslak al-Muttaqīn (1192 H /1778 M), Risālah fi Bayān Hukum asy-Syara'(1201 H / 1787 M), and Siyar al-Sālikīn ilā 'Ibādat Rabb al-'Âlaminn (1193H / 1779M - 1203 H / 1789 M). (Syarifuddin 2013) (Abdullah 2015).

4. Knowledge transmission from Shaykh Azhary Abdullah, including through fatwas to his followers in Palembang and also in rural areas, such as OKU and OKI. Then he also held Islamic education and religious preaching activities ( $d a^{\prime}$ wah bil lisan). Not only enlightenment but also moved the activities of Islamic religious education, this happened in 1843 in order to foster the identity of his people to become believers of Ash'ari, Muslim Shafi'i, Muhsin Junaidy, and Muttabi 'Samani. He also taught, from this teaching the transmission of his knowledge was absorbed by his students. His students are not only in Mecca, but he also teaches in Palembang and other South Sumatra regions such as in Baturaja and Ogan Komering Ilir (Zulkifli 1999). 
In addition, Shaykh Azhary Abdullah also transmitted his Islamic knowledge through writing (da'wah bil qalam), Shaykh Azhary Abdullah's work, among others are: Ațiyatu al-Rahman (1259 H /1843), Kitab al-Quran al-'Azìm (1264 H / 1848 M), Tuhfatu al-Murīdīna (1276 H/ 1859 M), Dalā-il al-khairāt (1240 H / 1825 M), Sirāj al-Hudā (1238 H) (Amin 2013).

5. Shaykh Kemas Azhary's knowledge transmission. The scientific transmission carried out by Shaykh Kemas Azhary also varied, i.e., through the spread of Islam or preaching ( $d a^{\prime} w a h$ bil lisan) to various regions, both Palembang, the interior of southern Sumatera and outside the southern Sumatra region of the city, even to foreign countries like Malaysia, Thailand, and others. Then, there was the transmission of Sufism with its Sammaniyah (Abdullah 1996).

Shaykh Kemas Azhary was a productive cleric. This can be proven from the books he wrote. Through the books he wrote, he transmitted his knowledge to the seekers of knowledge afterwards, even now his work of thought is still being explored. The existence of the transmission of knowledge through this paper can be said Shaykh Kemas Azhari has done da'wah bil qalam. The work of Shaykh Kemas Azhary. Among them are: 'Aqāid al-Imān (1309 H/ 1891 M), Badī' al-Zamān fì Bayān 'Aqāid al-Imān (1310 H /1892 M Irsyād al-Gulam fì Bayān 'Aqāid al-Islām (1318 H / 1900 M), Ta'alìm aṣ-Ṣalāh Farḍīyah (1319 H / 1901 M), Manāqib ay-Syaikh Muhammad Sammān al-Madanī (1331 H / 1912 M), Bìdāyatu al-'Ilmīyah (1354 H / pentahun cetak), Qiṣah al-Isrā' wa al-Mi'rāj (1355 H / pen-tahun cetak), Masāilu al-Muhtadì li ikhwāni al-Muhtadī (Herlina 2018).

6. Azhary Imam's knowledge transmission carried out by means of $d a^{\prime}$ wah bil lisan and da'wah bil qalam. This was revealed because he had high intellectual abilities and various statuses that he carried, namely as an ulema, Sufi, an excellent teacher, expert in medicine and also a writer. So that it was easy for him to transmit his knowledge through work, positions entrusted to him, and the roles he has carried out, namely among them as teachers of Islamic religion both in mosques and in people's homes (Kemas Andi Syarifuddin 2009). The fact is it is interesting about the scientific transmission that Azhary Imam had been doing and can read up to 
now is his writing, in his time he was very productive as evidenced by several works of Islamic knowledge he had produced. Azhary Imam's intellectual works included Najāh al-Insān wa Tasbịh al-Raḥman (1314 H/ 1896 M), Rāhat al-Qulūb (1318 H/ 1900 M), Hidayat an-Nisa (1319 H/1901 M), Riwāyat Șahīh al-Bukhari dan Anas bin Mālik, Tafsir surat an-najm ayat 8-9, Kaifiyat bai'at, Syarah Dalil Syara', Lațaif al-'Abidīn (1325 H/1907 M), Tāj aṣ-Ṣālihị̄n (1325 H / 1907 M), Risālat 'ilm al-Tawhị̂d (1908), Kitab Manāsik al-Haji al-Musamā bi Gāyah al-Māram (1334 H/ 1916 M), Risālah nikaḥ (1393 H / 1846 M), Safinah al-Gulam (Muhammad 2011).

\section{Conclusion}

Based on the descriptions above, it can be understood that the Palembang knowledge has an important role in spreading the Islamic sciences in Palembang, through the transmission of Islamic knowledge. Transmission of knowledge is carried out by Palembang scholars through two ways. First, there was the transmission of knowledge by direct means or teaching Islamic knowledge to his students. From Palembang Islamic intellectuals, there were only 5 who made direct transmissions (da'wah bi lisani), namely; Shaykh Syihabuddin al-Jawi al-Palimbani, Shaykh AbdusSamad al-Palimbani, Shaykh Azhary Abdullah, Shaykh Kemas Azhary, and Azhary Imam. Second, there was the transmission of knowledge by indirect means through writing (da'wah bil qalam), writing the results of his thoughts in the form of scientific works and literary works. This indirect transmission ( $d a^{\prime}$ wah bil qalam) was carried out by all Palembang Islamic intellectuals in this study, both Shaykh Syihabuddin al-Jawi al-Palimbani, Kemas Fakhruddin, Shaykh Abdus-Samad al-Palimbani, Shaykh Azhary Abdullah, Shaykh Kemas Azhary, and Azhary Imam. 


\section{Bibliography}

Abdullah. 1996... Shaghir. Syeikh Abdus Shamad Al-Palimbani: Ulama Shufi Dan Jihad Dunia Melayu. Kuala Lumpur: Khazanah Fathaniyah.

Abdullah, Mal An. 2015. Syaikh Abdus-Samad Al-Palimbani: Biografi Dan Warisan Keilmuan. Yogyakarta: Pustaka Pesantren.

Alimul H, A. Aziz. 2009. Kebutuhan Dasar Manusia Aplikasi Konsep Dan Proses Perawatan. Jakarta: Salemba Medika.

Amin, Abd Azim. 2013. “Pemikiran Aqidah Ahlussunah Wal Jama’ah Syaikh Muhammad Azhari Al-Palimbani Dalam Naskah Palembang 1842." Tamaddun 13(1).

Asrohah, Hanum. 1999. Sejarah Pendidikan Islam. Jakarta: Logos Wacana Ilmu. Azra, Azyumardi. 2013. Jaringan Ulama Timur Tengah Dan Kepulauan Nusantara Abad XVII Dan XVIII.: Akar Pembaharuan Islam Indonesia. Jakarta: Kencana Prenada Media Group.

Bruinessen, Martin Van. 1990. “Mencari Ilmu Dan Pahala Di Tanah Suci: Orang Nusantara Naik Haji (Seeking Knowledge and Merit: Indonesians on the Haj)." Ulumul Qur'an II(5): 42-49.

Drewes, GWJ. 1977. Directions for Travelers on the Mystic Path. Nijhoff: The Hague. Fathurahman, Oman. 2015. Filologi Indonesia: Teori Dan Metode. Jakarta: Kencana Prenada.

Garraghan, Gilbert J. A. 1957. Guide to Historical Method, Ed. Jean Delanglez. New York: Fordham University Press.

Herlina. 2018. “Tradisi Dan Warisan Intelektual Ulama Palembang Abad Ke-18

Hingga Awal Abad Ke-20 Masehi." UIN Raden Fatah Palembang.

Junaedi, Mansur dan Mahfud. 2015. Rekonstruksi Sejarah Pendidikan Islam Di Indonesia. Jakarta: Dirjen Kelembagaan Agama Islam. Depag RI.

Kemas Andi Syarifuddin. 2009. Azhari Bin Makruf: Biografi, Karya Dan Ajaranya. Seri Ulama Palembang. Palembang.

Littlejohn, Stephen W. 1989. Theories of Human Communication, 3rd Edition. California: Wadsworth Publishing Company. 
Muhammad, Nyimas Anisah. 2011. Muhammad Azhari Ulama Palembang: Biografi, Perjalanan Intelektual Dan Karya-Karyanya. Yogyakarta: Idea Press.

Munip. 2010. Transmisi Pengetahuan Timur Tengah Ke Indonesia: Studi Tentang

Penerjemahan Buku Berbahasa Arab Di Indonesia 1950-2004. Jakarta: Puslitbang Lektur Keagaamaan Balitbang dan Diklat Kemenag RI,.

Nata, Abuddin. 2014. Sejarah Pendidikan Islam. Jakarta: Kencana Prenadamedia Group. Rahim, Husni. 1998. Sistem Otoritas Dan Administrasi Islam: Studi Tentang Pejabat Agama Masa Kesultanan Dan Kolonial Palembang. Jakarta: Logos.

Safwan, Mardanas. 2004. Sultan Mahmud Badaruddin II (1767-1852). Jakarta: Bharata.

Steenbrink, K A. 1984. Beberapa Aspek Tentang Islam Di Indonesia Abad Ke 19. Jakarta: Bulan Bintang.

Sukardi, Ismail. 2014. Madrasah Dan Pergolakan Sosial Politik Di Keresidenan Palembang, 1925-1942. Yogyakarta: Idea Press.

Syarifuddin, Kemas Andi. 2013. 101 Ulama Sumatera Selatan. Yogyakarta: Forpres Sumsel Ar Ruzz Nedia.

Wargadalem, Farida R. 2017. Kesultanan Palembang Dalam Pusaran Konflik (1804-1825). Jakarta: KPG (Kepustakaan Populer Gramedia) Ecole Francaise d'Extreme-Orient. Zulkifli. 1999. Ulama Sumatera Selatan: Pemikiran Dan Peranannya Dalam Lintasan Sejarah. Palembang: Universitas Sriwijaya. 